\title{
Plexin DI is ubiquitously expressed on tumor vessels and tumor cells in solid malignancies
}

\author{
Ilse Roodink*1, Kiek Verrijp ${ }^{1}$, Jos Raats ${ }^{2}$ and William PJ Leenders ${ }^{1}$
}

Address: ${ }^{1}$ Dept. of Pathology, Radboud University Nijmegen Medical Centre, P.O. Box 9101, 6500 HB, Nijmegen, The Netherlands and ${ }^{2}$ ModiQuest B.V. and Dept. of Biomolecular Chemistry, Nijmegen Centre for Molecular Life Sciences, Heyendaalseweg 135, 6525 AJ, Nijmegen, The Netherlands

Email: Ilse Roodink* - I.Roodink@pathol.umcn.nl; Kiek Verrijp - K.Verrijp@pathol.umcn.nl; Jos Raats - jraats@modiquest.com; William PJ Leenders - W.Leenders@pathol.umcn.nl

* Corresponding author

Published: 25 August 2009

BMC Cancer 2009, 9:297 doi:10.1 |86/|47|-2407-9-297
Received: 30 March 2009

Accepted: 25 August 2009

This article is available from: http://www.biomedcentral.com//47/-2407/9/297

(C) 2009 Roodink et al; licensee BioMed Central Ltd.

This is an Open Access article distributed under the terms of the Creative Commons Attribution License (http://creativecommons.org/licenses/by/2.0), which permits unrestricted use, distribution, and reproduction in any medium, provided the original work is properly cited.

\begin{abstract}
Background: Plexin DI is expressed on both tumor-associated endothelium and malignant cells in a number of clinical brain tumors. Recently we demonstrated that Plexin DI expression is correlated with tumor invasion level and metastasis in a human melanoma progression series. The objective of this study was to examine whether Plexin DI might be clinically useful as a pan-tumor vessel and pan-tumor cell target in solid tumors.

Methods: We examined Plexin DI expression in clinical solid tumors $(n=77)$ of different origin, a selection of pre-malignant lesions $(n=29)$ and a variety of non-tumor related tissues $(n=52)$ by immunohistochemistry. Signals were verified in a selection of tissues via mRNA in situ hybridization.

Results: Plexin DI is abundantly expressed on both activated established tumor vasculature and malignant cells in the majority of primary and metastatic clinical tumors, as well as on macrophages and fibroblasts. Importantly, in non-tumor related tissues Plexin DI expression is restricted to a subset of, presumably activated, fibroblasts and macrophages.

Conclusion: We demonstrate that Plexin DI is in general ubiquitously expressed in tumor but not normal vasculature, as well as in malignant cells in a wide range of human tissues. This expression profile highlights Plexin DI as a potentially valuable therapeutic target in clinical solid tumors, enabling simultaneous targeting of different tumor compartments.
\end{abstract}

\section{Background}

Interference with a tumor's blood supply is an attractive approach to inhibit tumor growth and dissemination. Thereto, many research focused on targeting the angiogenic process via inhibition of the Vascular endothelial Growth Factor (VEGF-A) pathway. Despite promising results in animal tumor models in which anti-VEGF ther- apy translates into potent anti-tumor effects [1-3], implementation of these therapies for a number of tumor types in the clinic has now learned that they, either or not in combination with chemotherapy, do increase quality of life or modestly prolong survival [4-7], but lack curative effects $[8,9]$. This discrepancy may be partly due to the high heterogeneity of the vasculature [10-12]: in estab- 
lished clinical tumors all possible maturation stages may be represented, only a small fraction of which may be susceptible to VEGF inhibition [13]. This situation contrasts that in fast growing animal tumors in which the entire population of tumor vessels may be in a synchronized maturation stage. In addition, we and others described that in organs with intrinsically high vessel densities, tumors and metastases are able to grow in an angiogenesis-independent fashion via co-option of pre-existing blood vessels [14-18]. This provides tumors with a route of escape which makes them (partially) unsusceptible to anti-angiogenic compounds. Even more, anti-angiogenesis may drive a shift in brain tumors from an angiogenic to a co-opting phenotype [19-21]. Therefore, vascular targeting therapy in which the existing tumor vascular bed, angiogenic or pre-existent, is attacked with the aim to induce acute tumor-specific coagulation may be an attractive additional approach to deprive a tumor from blood supply. To apply vascular targeting therapies, targetable markers that discriminate tumor vessels from normal vasculature are needed. We previously described that Plexin D1 (PLXND1) could be such a target [22].

PLXND1 belongs to a family of large transmembrane proteins that are receptors for neuropilins and semaphorins $[23,24]$. Plexins are involved in regulation of axonal patterning during embryonic development [25-28]. Apart from neuronal cells, PLXND1 is also expressed by vascular endothelial cells during embryogenesis [29] and is of pivotal importance for vascular patterning, as illustrated by the fact that PLXND1 knock-down in mice and zebrafish results in abnormal development of the cardiovascular system [30-32].

We previously demonstrated that PLXND1 is also specifically expressed on vascular endothelium during tumorassociated angiogenesis in a mouse xenograft model of cerebral melanoma metastasis and in a number of human brain tumors, both of primary and metastatic origin [22]. Importantly, expression of this protein was also found on tumor cells in these tumors [22], and this expression correlates with malignancy grade in a human melanoma progression series: whereas PLXND1 is abundantly expressed in both invasive primary and disseminated melanomas, both in the vasculature and in tumor cells, its expression was absent in benign melanocytic lesions and melanomas in situ, except for expression on macrophages and fibroblasts [33].

PLXND1 contains in its intracellular domain consensus Rac/RhoA signalling motifs [29], suggestive of a role in cytoskeletal rearrangements and cell motility, processes which are fundamental for both tumor angiogenesis and metastasis. PLXND1 may thus be functionally involved in tumor development in multiple ways.
The expression profile of PLXND1 suggests that it may be a valuable tumor target for established solid tumors, allowing simultaneous targeting of different tumor compartments, i.e. vessels and tumor cells. To examine whether PLXND1 might be clinically useful as a pantumor vessel and pan-tumor cell target in solid tumors we analyzed PLXND1 expression in a wide range of human tumors of different origin, various pre-malignant and non-tumor related tissues by immunohistochemistry and mRNA in situ hybridization.

\section{Methods}

\section{Tissue samples}

Primary and metastatic tumor tissues of different origin (n = 77), among them 15 paired samples of human primary and metastatic lesions and various pre-malignant lesions $(n=29)$, were selected from the archives of the Department of Pathology and Radiology of the Radboud University Nijmegen Medical Centre. Furthermore, non-tumor related tissues $(n=52)$ were obtained. The study was performed according to the guidelines of the Code for proper secondary use of human tissue in the Netherlands (Version 2002, Federation of Biomedical Scientific Societies, http://www.federa.org).

\section{Immunohistochemistry}

After deparaffinization and blocking of endogenous peroxidase activity, antigen retrieval was performed by treatment with pronase according to standard protocols [33]. Non-specific binding sites were blocked by incubation with $20 \%$ normal horse serum. Slides were incubated for 1 hr with single domain antibody A12, which was previously selected against a PLXND1-specific peptide [22]. A12 was detected by sequential incubations with the mouse anti-VSV-G P5D4, biotinylated anti-mouse IgG (Vector, Burlingame, CA), and avidin-biotin peroxidase complex (Vector). Peroxidase was visualized by the 3amino-9-ethylcarbazole (ScyTek, Logan, UT) peroxidase reaction, with haematoxylin as counterstain. All incubations were performed at room temperature. Blood vessel origin was confirmed by endothelial stainings on serial sections with anti-human CD31 antibody (DAKO, Glostrup, Denmark).

In a selection of tissues, macrophage identity was confirmed by double staining for PLXND1 and CD68. In short, the above mentioned avidin-biotin peroxidase procedure was used to detect PLXND1 via rabbit anti-VSV-G antiserum (Sigma Chemical Co., Zwijndrecht, The Netherlands). Following visualization, avidin-biotin was blocked according to standard protocols. Slides were successively incubated with normal horse serum, mouse antihuman CD68 antibody (DAKO) overnight at $4{ }^{\circ} \mathrm{C}$, biotinylated anti-mouse IgG (Vector) and avidin-biotin alkaline phosphatase (AP) complex (Vector) at RT. AP was 
visualized with a mixture of naphthol phosphate (Sigma), levamisole (Sigma), and Fast Blue (Sigma).

\section{PLXNDI mRNA In Situ Hybridization}

To explore whether the PLXND1 transcript is also specifically present in malignant tissues, we performed mRNA in situ hybridizations on 28 of the 158 paraffin-embedded tissues analyzed by immunohistochemistry (malignant lesions, $\mathrm{n}=15$; non-tumor related samples, $\mathrm{n}=13$ ) as previously described [22]. In brief, digoxigenin-labelled sense and antisense human PLXND1 RNA probes, located in the 3'-untranslated region, were generated by in vitro transcription from a PLXND1 PCR product which was flanked by T7 and T3 promoters as described [29]. Following deparaffinization, $4 \mu \mathrm{m}$ tumor sections were treated with proteinase $\mathrm{K}$ (Roche, Almere, The Netherlands) at $37^{\circ} \mathrm{C}$ for 15 minutes and post-fixed in formaldehyde. Non-specific binding sites were blocked by incubation with acetic anhydride (Sigma) at room temperature. Tissues were hybridized with digoxigenin-labelled RNA probes at $63^{\circ} \mathrm{C}$ with $200 \mathrm{ng} / \mathrm{ml}$ probe. Single stranded non-hybridized RNA was degraded with RNAse T1 (2 units $/ \mathrm{ml}$ ) at $37^{\circ} \mathrm{C}$ for 30 minutes. After subsequent preincubation with normal sheep serum, the slides were incubated with alkaline phosphatase-conjugated sheep anti-digoxigenin antibody (Roche) at room temperature for 1 hour. Alkaline phosphatase was visualized using nitro blue tetrazolium (NBT; Roche) and 5-bromo-4chloro-3-indolyl phosphate (BCIP; Roche) as substrate with nuclear fast red as counterstain. Specificity of hybridizations was verified by performing control hybridizations with sense probe.

\section{Results}

To explore whether PLXND1 may be clinically useful as a pan-tumor endothelium and a pan-tumor cell target we examined the expression profile of this protein in a large variety of human tissue samples. As summarized in Table 1 , PLXND1 is abundantly expressed in both the vasculature and malignant cells in the majority of clinical tumors, whereas in pre-malignant lesions the protein is present at lower levels or, like in non-tumor related tissues, almost completely absent (Table 2). Figure 1 shows vascular (arrows) and tumor cell expression of PLXND1 in representative samples of brain metastasis of adenocarcinoma (A), glioblastoma multiforme (B), neuro-endocrine lung tumor (C), ovarian adenocarcinoma (D), and prostatic urothelial cell carcinoma (E). The insets in A and B show corresponding in situ hybridization signals. Vascular and tumor cell-associated PLXND1 expression was absent in 3 out of 5 medullary breast carcinomas, one out of 5 cervical squamous cell carcinomas, and all examined vulvar squamous cell carcinomas (Table 1). A representative sample of vulvar squamous cell carcinoma is shown in figure $1 \mathrm{~F}$. In addition, two low grade astrocytomas showed infrequent vascular and tumor cell-associated PLXND1 expression (Table 1). As shown in figure $2 \mathrm{~A}$ through $\mathrm{F}$ no significant differences in staining pattern and intensity of vascular structures (arrows) and malignant cells could be observed between primary ductal breast carcinoma (A) and a corresponding lymph node metastasis (B), colon adenocarcinoma (C) and a corresponding liver metastasis (D) and renal cell carcinoma (E) and a corresponding brain metastasis (F, the inset shows corresponding in situ hybridization signal).

To examine whether PLXND1 is expressed on angiogenic vessels under physiological conditions, we also investigated expression in endometrium. In 3 out of 5 proliferative phase endometria some vessels stained positive for PLXND1 (Table 2). Figure 2G and $2 \mathrm{H}$ show lack of PLXND1 protein and transcript (insets) in normal human cerebral cortex and heart tissue. The granular staining pattern in cerebral neurons $(G)$ and cardiac myocytes $(H)$ is presumably due to aspecific binding of single domain antibodies to lipofuscine as this is observed with other non-related single domain antibodies too (not shown). Apart from tumor-associated endothelium and tumor cells, PLXND1 expression was also observed in subsets of fibroblast- and macrophage-like cells in both tumor samples and pre-malignant and non-tumor related tissues. Identity of macrophages was confirmed by double staining a selection of analyzed tissues for PLXND1 and CD68 (not shown).

\section{Discussion}

In previous work we showed that PLXND1 is expressed in endothelial cells during developmental and tumor-associated angiogenesis $[22,29]$. Besides vascular expression, high PLXND1 expression was also found on tumor cells in cerebral melanoma metastases. Whereas a role of PLXND1 in vessel patterning during development is well established [30-32], the functional consequences of PLXND1 expression on tumor cells and vessels are less clear. We recently demonstrated that PLXND1 expression is correlated with tumor invasion and metastasis in a human melanoma progression series [33]. However, the PLXND1 ligands Semaphorin 3E and 4A inhibit, rather than promote, (tumor) angiogenesis [33,34]. Moreover, Semaphorin 3E even exhibits anti-tumor and anti-metastatic properties [33,35].

Here we show that PLXND1 is expressed at high levels on activated established tumor vasculature in a variety of primary and metastatic human malignancies, whereas in non-tumor related tissues PLXND1 expression is restricted to a subset of, presumably activated, fibroblasts and macrophages. These results are in agreement with our previous observations in clinical brain tumors of different origin [22] and a series of cutaneous melanocytic lesions 
Table I: Plexin DI expression in solid malignancies.

\begin{tabular}{|c|c|c|c|c|c|}
\hline \multirow[t]{2}{*}{ Malignant tissue } & \multicolumn{4}{|c|}{ PLXNDI expression } & \multirow[t]{2}{*}{ Remarks } \\
\hline & Endothelial cells & Tumor cells & Subset of macrophages & Subset of fibroblasts & \\
\hline \multicolumn{6}{|l|}{ Paired samples } \\
\hline $\begin{array}{l}\text { Medullary breast carcinoma } \\
(n=1)\end{array}$ & - & - & + & + & Plasma cells also positive \\
\hline $\begin{array}{l}\text { Lymph node metastasis } \\
(\mathrm{n}=\mathrm{I})\end{array}$ & Subset & - & + & n.d. & \\
\hline $\begin{array}{l}\text { Ductal breast carcinoma } \\
(\mathrm{n}=8)\end{array}$ & + & + & + & + & $\begin{array}{l}\text { Some plasma cells also } \\
\text { positive }\end{array}$ \\
\hline $\begin{array}{l}\text { Lymph node metastasis } \\
(\mathrm{n}=8)\end{array}$ & + & + & + & + & \\
\hline $\begin{array}{l}\text { Adenocarcinoma of colon } \\
(n=4)\end{array}$ & + & + & + & + & \\
\hline Liver metastasis $(n=4)$ & + & + & + & + & \\
\hline $\begin{array}{l}\text { Alveolar soft part sarcoma of } \\
\text { femur }(n=1)\end{array}$ & + & + & n.d. & n.d. & \\
\hline Brain metastasis $(n=1)$ & + & + & n.d. & n.d. & \\
\hline Renal cell carcinoma $(n=1)$ & + & + & n.d. & n.d. & \\
\hline Brain metastasis $(n=1)$ & + & + & n.d. & n.d. & \\
\hline
\end{tabular}

\section{Non-paired samples}

\begin{tabular}{lcccc}
\hline $\begin{array}{l}\text { Adenocarcinoma of coecum } \\
(n=1)\end{array}$ & + & + & + & - \\
\hline $\begin{array}{l}\text { Adenocarcinoma of } \\
\text { oesophagus }(n=I)\end{array}$ & + & + & + & - \\
\hline $\begin{array}{l}\text { Adenocarcinoma of ovary } \\
(n=1)\end{array}$ & Subset & + & + & + \\
\hline $\begin{array}{l}\text { Adenocarcinoma of prostate } \\
(n=1)\end{array}$ & + & + & - & - \\
\hline
\end{tabular}


Table I: Plexin DI expression in solid malignancies. (Continued)

\begin{tabular}{lllll}
\hline $\begin{array}{l}\text { Adenocarcinoma of rectum } \\
(\mathrm{n}=5)\end{array}$ & + & + & + & + \\
\hline $\begin{array}{l}\text { Brain metastasis of } \\
\text { adenocarcinoma }(\mathrm{n}=4)\end{array}$ & + & + & n.d. & n.d. \\
\hline $\begin{array}{l}\text { Liver metastasis of } \\
\text { adenocarcinoma colon } \\
(\mathrm{n}=8)\end{array}$ & + & + & + & + \\
\hline $\begin{array}{l}\text { Ovary metastasis of } \\
\text { adenocarcinoma colon } \\
(\mathrm{n}=1)\end{array}$ & - & + & - & - \\
\hline
\end{tabular}

\begin{tabular}{lcccc}
\hline $\begin{array}{l}\text { Low grade astrocytoma } \\
(\mathrm{n}=2)\end{array}$ & Subset & Subset & n.d. & n.d. \\
\hline $\begin{array}{l}\text { Glioblastoma Multiforme } \\
(\mathrm{n}=3)\end{array}$ & + & + & n.d. & n.d. \\
\hline Medulloblastoma $(\mathrm{n}=1)$ & + & + & n.d. & n.d. \\
\hline
\end{tabular}

\begin{tabular}{l}
$\begin{array}{l}\text { Neuro-endocrine tumor of } \\
\text { lung }(\mathrm{n}=2)\end{array}$ \\
\hline
\end{tabular}

\begin{tabular}{lcccc}
\hline $\begin{array}{l}\text { Medullary breast carcinoma } \\
\text { of }(n=4)\end{array}$ & + & + & + & - \\
\hline $\begin{array}{l}\text { Lymph node metastasis of } \\
\text { ductal breast carcinoma } \\
(n=I)\end{array}$ & Subset & + & - & $\begin{array}{l}2 \text { samples negative vessels } \\
\text { and tumor cells }\end{array}$ \\
\hline
\end{tabular}

\begin{tabular}{|c|c|c|c|c|c|}
\hline $\begin{array}{l}\text { Squamous cell carcinoma of } \\
\text { cervix }(n=5)\end{array}$ & Subset & + & + & - & $\begin{array}{l}\text { I sample negative vessels } \\
\text { and tumor cells }\end{array}$ \\
\hline $\begin{array}{l}\text { Squamous cell carcinoma of } \\
\text { vulva }(n=5)\end{array}$ & - & - & + & + & \\
\hline
\end{tabular}

Urothelial cell carcinoma of $\quad+\quad+$
prostate $(n=2)$

+ , corresponding cell type expresses PLXNDI

-, PLXNDI expression is absent in corresponding cell type

n.d., corresponding cell type is not detected

representing different stages of melanoma progression [33]. So, for subsets of tumor types in which vessel activation has occurred, PLXND1 may be a valuable candidate protein for vascular targeting approaches. Indeed, the anti-PLXND1 single domain antibody A12 homes to and accumulates in tumor vessels [22].
Successful vascular targeting has also been achieved with agents directed against molecules of which expression is restricted to vessels in early stages of angiogenesis. Examples are the L19 single chain antibody, directed against the ED-B fragment of fibronectin which targets vasculature in actively growing tumors [36], whereas this single chain 
Table 2: Plexin DI expression in pre-malignant and non-tumor related tissues.

\begin{tabular}{|c|c|c|c|c|}
\hline \multirow[t]{2}{*}{ Tissue } & \multicolumn{3}{|c|}{ PLXNDI expression } & \multirow[t]{2}{*}{ Remarks } \\
\hline & Endothelial cells & Subsets of macrophages & Subsets of fibroblasts & \\
\hline \multicolumn{5}{|l|}{ Pre-malignant samples } \\
\hline $\begin{array}{l}\text { Ductal carcinoma in situ of breast } \\
(n=5)\end{array}$ & + & + & + & Weak staining of tumor cells \\
\hline $\begin{array}{l}\text { Lobular carcinoma in situ of breast } \\
(n=3)\end{array}$ & Weak & + & + & Weak staining of tumor cells \\
\hline \multicolumn{5}{|l|}{$\begin{array}{l}\text { Vulvar intraepithelial neoplasia } \\
\text { (VIN) }\end{array}$} \\
\hline $\begin{array}{l}\text { Classic VIN III, HPV negative } \\
(n=5)\end{array}$ & - & + & + & \\
\hline $\begin{array}{l}\text { Classic VIN III, HPV positive } \\
(n=8)\end{array}$ & - & + & + & \\
\hline Differentiated VIN III $(n=8)$ & - & + & n.d. & \\
\hline
\end{tabular}

\section{Non-tumor related samples}

\begin{tabular}{|c|c|c|c|c|}
\hline Bladder $(n=1)$ & - & + & - & \\
\hline \multicolumn{5}{|l|}{ Blood vessel } \\
\hline Atherosclerosis $(n=6)$ & - & + & - & \\
\hline Fatty streaks $(n=1)$ & - & + & - & \\
\hline Bone marrow $(n=2)$ & n.d. & - & - & \\
\hline \multicolumn{5}{|l|}{ Brain } \\
\hline Cortex $(n=1)$ & - & n.d. & n.d. & Some neurons perinuclear staining \\
\hline Alzheimer and CAA $(n=1)$ & - & n.d & n.d. & \\
\hline Multiple Sclerosis $(\mathrm{n}=2)$ & - & n.d & n.d. & \\
\hline \multicolumn{5}{|l|}{ Breast } \\
\hline Normal breast $(\mathrm{n}=2)$ & - & - & - & $\begin{array}{l}\text { Some epithelial cells perinuclear } \\
\text { staining }\end{array}$ \\
\hline Ductal hyperplasia $(\mathrm{n}=\mathrm{I})$ & - & + & - & $\begin{array}{l}\text { Focal epithelial cells perinuclear } \\
\text { staining }\end{array}$ \\
\hline
\end{tabular}

Endometrium
Proliferation phase $(n=5)$
Subset $(n=3)$
$+$
n.d. 
Table 2: Plexin DI expression in pre-malignant and non-tumor related tissues. (Continued)

\begin{tabular}{|c|c|c|c|c|}
\hline Secretion phase $(n=4)$ & - & + & n.d. & \\
\hline $\begin{array}{l}\text { Secretion/menstruation phase } \\
(n=I)\end{array}$ & - & + & n.d. & \\
\hline Endometriosis interna $(n=1)$ & - & + & n.d. & \\
\hline Heart $(n=1)$ & - & n.d & n.d & Myocytes perinuclear staining \\
\hline Large intestine $(n=1)$ & - & + & + & $\begin{array}{l}\text { Some epithelial cells perinuclear } \\
\text { staining }\end{array}$ \\
\hline Liver $(n=1)$ & - & + & n.d. & $\begin{array}{l}\text { Some hepatocytes perinuclear } \\
\text { staining }\end{array}$ \\
\hline Lung $(n=2)$ & - & + & n.d. & \\
\hline Oesophagus $(n=1)$ & - & + & - & \\
\hline Pancreas $(n=1)$ & - & n.d & n.d. & $\begin{array}{l}\text { Perinuclear staining Islets of } \\
\text { Langerhans }\end{array}$ \\
\hline Pituitary gland $(n=1)$ & - & n.d. & n.d. & $\begin{array}{l}\text { Some epithelial cells perinuclear } \\
\text { staining }\end{array}$ \\
\hline Prostate $(\mathrm{n}=1)$ & - & - & n.d. & $\begin{array}{l}\text { Some epithelial cells perinuclear } \\
\text { staining }\end{array}$ \\
\hline Small intestine $(n=1)$ & - & + & + & $\begin{array}{l}\text { Some epithelial cells perinuclear } \\
\text { staining }\end{array}$ \\
\hline Spleen $(\mathrm{n}=1)$ & - & + & n.d. & \\
\hline Thyroid gland $(n=1)$ & - & + & n.d. & $\begin{array}{l}\text { Some epithelial cells perinuclear } \\
\text { staining }\end{array}$ \\
\hline \multicolumn{5}{|l|}{ Vulva } \\
\hline Normal vulva $(n=6)$ & - & + & + & \\
\hline Lichen sclerosus $(n=6)$ & - & + & + & \\
\hline
\end{tabular}

+ , corresponding cell type expresses PLXNDI

-, PLXNDI expression is absent in corresponding cell type

n.d., corresponding cell type is not detected

antibody is unable to detect quiescent endothelium in low grade malignancies [37]. Targeted radiotherapy with radiolabeled RGD peptides, recognizing integrin $\alpha v \beta 3$ on newly formed endothelial cells, led to reduced growth of xenografts in mouse models of cancer [38-40]. Furthermore, chimeric proteins, consisting of antibodies against the tumor vessel marker vascular cell adhesion molecule 1 (VCAM-1), fused to soluble Tissue Factor, induced tumor specific blood clotting, tumor necrosis and growth delay in different xenograft models [41].
Due to vessel heterogeneity in tumors [10-12,42] it is unlikely that one single marker will behave as a targetable pan-tumor-endothelial antigen, but appropriate mixtures of different tumor vessel targeting agents, including antiPLXND1 antibodies, may allow specific targeting of the majority of tumor vessels. For instance, to effectively starve tumors like low grade gliomas, which (partly) thrive on quiescent vasculature, targeting agents that recognize co-opted vessels in infiltrative tumor areas need to be developed. It remains to be seen whether such targets 

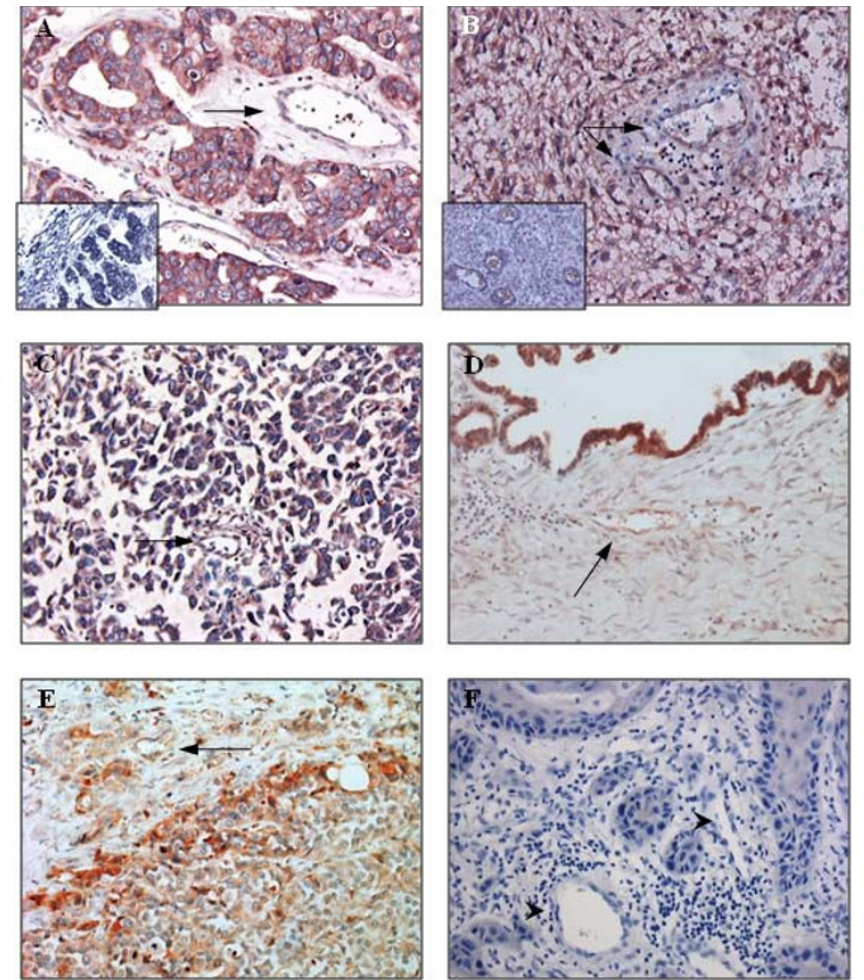

\section{Figure I}

\section{PLXNDI expression in representative clinical tumor} samples. Immunohistochemical analyses using a single domain antibody against PLXNDI (Magnification $\times 200$ ). PLXNDI is abundantly expressed in adenocarcinoma brain metastases $(A)$, glioblastomas multiforme $(B)$, neuro-endocrine lung tumors $(C)$, an ovarian adenocarcinoma (D), and prostatic urothelial cell carcinomas (E). The arrows point at PLXNDI-positive vasculature. PLXNDI is absent in both tumor vasculature (arrowheads) and tumor cells in vulvar squamous cell carcinomas ( $F$ ). The insets in $A$ and $B$ show corresponding PLXNDI mRNA in situ hybridization analyses (Magnification $\times 200$ ).

can be identified and, if so, whether such strategy holds promise for treatment of brain tumors, as it will include some toxicity for interspersed normal brain in infiltrative tumor areas.

Apart from vascular PLXND1 expression in tumors, the protein is also abundantly expressed on tumor cells in a wide range of clinical solid tumors which reinforces this membrane protein as a tumor target, since it allows simultaneous targeting of different tumor compartments with one compound. Since all tumor metastases tested, except for one lymph node metastasis of a medullary breast carcinoma, expressed high levels of this protein, both on vessels and tumor cells, a PLXND1-directed seek-and-destroy strategy may therefore indeed be feasible.
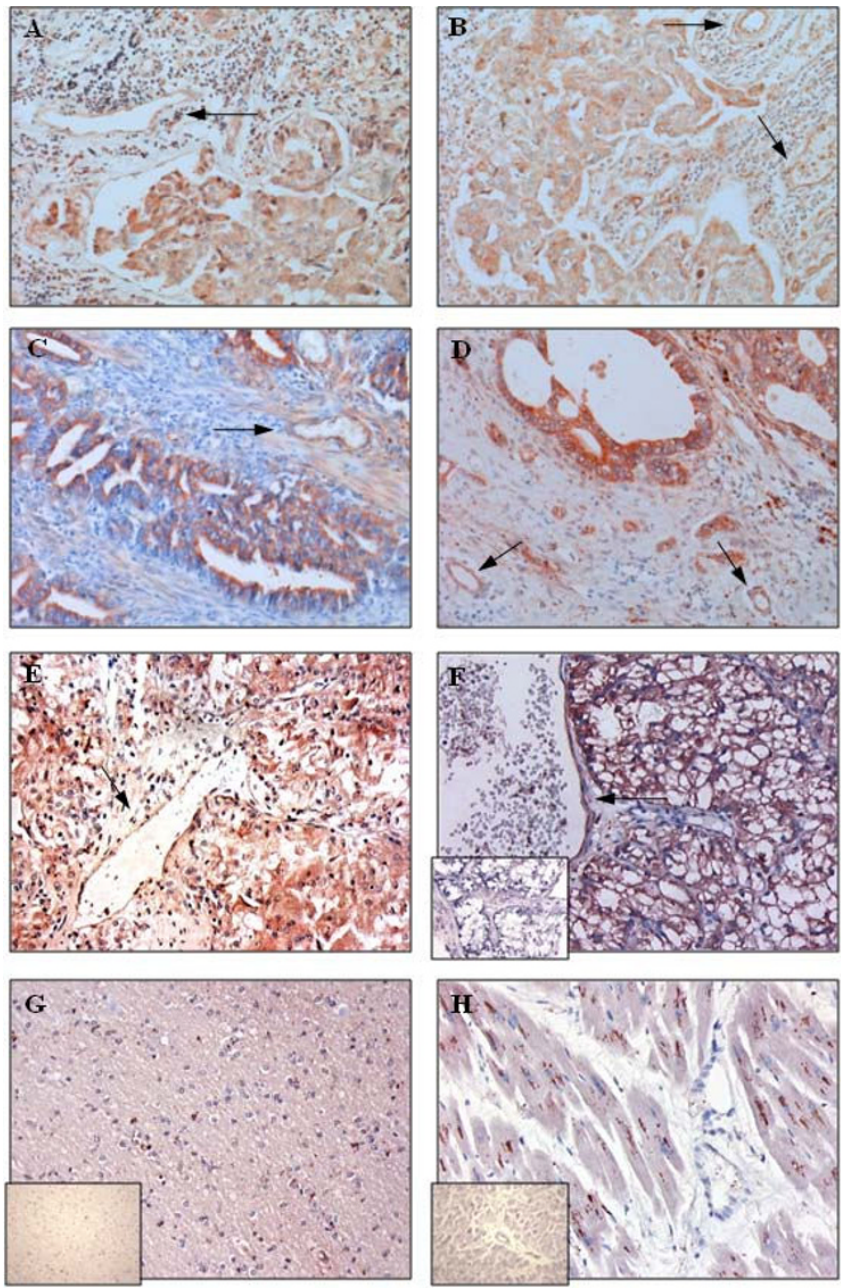

Figure 2

PLXNDI expression in representative clinical (tumor) samples. Immunohistochemical analyses using a single domain antibody against PLXNDI (Magnification $\times 200$ ). PLXNDI is expressed at high levels in primary ductal breast carcinomas $(A)$ and corresponding lymph node metastases (B), colon adenocarcinomas (C) and corresponding liver metastases $(D)$ and a renal cell carcinoma $(E)$ and corresponding brain metastasis (F). The arrows point at PLXNDIexpressing tumor vessels. PLXNDI is not detected in normal human cerebral cortex $(\mathrm{G})$ and heart $(\mathrm{H})$ tissue samples. The insets in $\mathrm{F}, \mathrm{G}$ and $\mathrm{H}$ show corresponding PLXNDI mRNA in situ hybridization analyses (Magnification $\times 200$ ).

Despite its abundant expression in many different tumor types PLXND1 was not expressed on tumor cells and vessels in a subset of medullary breast carcinomas. Interestingly, these relatively rare tumors generally have a favorable prognosis [43]. It is tempting to speculate that PLXND1 expression is generally correlated with increased malignancy grade. The only other tumor type in our series which lacked vascular and tumor cell-associated PLXND1 
expression was vulvar squamous cell carcinoma. Because the increased microvessel density in these tumors suggests angiogenesis [44], the lack of PLXND1 on vessels in these tumors was unexpected [22]. Whether a lack of PLXND1 expression on these vessels is related to a more mature state can only be speculated upon. Physiological angiogenesis in proliferative phase endometria has been described to occur mainly in a non-sprouting fashion via vessel elongation [45] which may explain the appearance of vascular PLXND1 in only a small subset of vessels in such tissue.

\section{Conclusion}

We demonstrated that PLXND1 is in general ubiquitously expressed in tumor but not normal vasculature, as well as in malignant cells in a wide range of human (tumor) tissues. This expression pattern warrants further investigation towards PLXND1 as a therapeutic target in oncology.

\section{Competing interests}

The authors declare that they have no competing interests.

\section{Authors' contributions}

IR performed the immunohistochemical analyses. KV carried out mRNA in situ hybridization and assisted in the interpretation of the results. JR participated in the design of the study and provided general support. IR and WPJL were responsible for experimental design, interpretation of the results and writing the manuscript. All authors read and approved the final manuscript.

\section{References}

I. Mendel DB, Laird AD, Xin X, Louie SG, Christensen JG, Li G, Schreck RE, Abrams TJ, Ngai TJ, Lee LB: In vivo antitumor activity of SUI I 248, a novel tyrosine kinase inhibitor targeting vascular endothelial growth factor and platelet-derived growth factor receptors: determination of a pharmacokinetic/pharmacodynamic relationship. Clin Cancer Res 2003, 9:327-337.

2. Wilhelm SM, Carter C, Tang L, Wilkie D, McNabola A, Rong H, Chen C, Zhang $X$, Vincent P, McHugh M: BAY 43-9006 exhibits broad spectrum oral antitumor activity and targets the RAF/MEK/ ERK pathway and receptor tyrosine kinases involved in tumor progression and angiogenesis. Cancer Res 2004, 64:7099-7109.

3. Presta LG, Chen H, O'Connor SJ, Chisholm V, Meng YG, Krummen L, Winkler M, Ferrara N: Humanization of an anti-vascular endothelial growth factor monoclonal antibody for the therapy of solid tumors and other disorders. Cancer Res 1997, 57:4593-4599.

4. Motzer RJ, Hutson TE, Tomczak P, Michaelson MD, Bukowski RM, Rixe O, Oudard S, Negrier S, Szczylik C, Kim ST: Sunitinib versus interferon alfa in metastatic renal-cell carcinoma. N Engl J Med 2007, 356: II 15 - 24.

5. Escudier B, Pluzanska A, Koralewski P, Ravaud A, Bracarda S, Szczylik C, Chevreau C, Filipek M, Melichar B, Bajetta E: Bevacizumab plus interferon alfa-2a for treatment of metastatic renal cell carcinoma: a randomised, double-blind phase III trial. Lancet 2007, 370:2103-21II.

6. Hurwitz H, Fehrenbacher L, Novotny W, Cartwright T, Hainsworth J, Heim W, Berlin J, Baron A, Griffing S, Holmgren E: Bevacizumab plus irinotecan, fluorouracil, and leucovorin for metastatic colorectal cancer. N EnglJ Med 2004, 350:2335-2342.
7. Herbst RS, O'Neill VJ, Fehrenbacher L, Belani CP, Bonomi PD, Hart L, Melnyk O, Ramies D, Lin M, Sandler A: Phase II study of efficacy and safety of bevacizumab in combination with chemotherapy or erlotinib compared with chemotherapy alone for treatment of recurrent or refractory non small-cell lung cancer. J Clin Oncol 2007, 25:4743-4750.

8. Eichhorn ME, Strieth S, Dellian M: Anti-vascular tumor therapy: recent advances, pitfalls and clinical perspectives. Drug Resist Updat 2004, 7:125-138.

9. Narayana A, Kelly P, Golfinos J, Parker E, Johnson G, Knopp E, Zagzag $D$, Fischer I, Raza S, Medabalmi P: Antiangiogenic therapy using bevacizumab in recurrent high-grade glioma: impact on local control and patient survival. I Neurosurg 2009, I 1 0:173-180.

10. Roodink I, van der LJ, Kusters B, Wesseling P, Verrijp K, de WR, Leenders W: Development of the tumor vascular bed in response to hypoxia-induced VEGF-A differs from that in tumors with constitutive VEGF-A expression. Int J Cancer 2006, II 9:2054-2062.

II. Trepel M, Arap W, Pasqualini R: In vivo phage display and vascular heterogeneity: implications for targeted medicine. Curr Opin Chem Biol 2002, 6:399-404.

12. Joyce JA, Laakkonen P, Bernasconi M, Bergers G, Ruoslahti E, Hanahan $D$ : Stage-specific vascular markers revealed by phage display in a mouse model of pancreatic islet tumorigenesis. Cancer Cell 2003, 4:393-403.

13. Bergers G, Song S, Meyer-Morse N, Bergsland E, Hanahan D: Benefits of targeting both pericytes and endothelial cells in the tumor vasculature with kinase inhibitors. J Clin Invest 2003, I II:I287-I 295 .

14. Kusters B, Leenders WP, Wesseling P, Smits D, Verrijp K, Ruiter DJ, Peters JP, Der Kogel AJ, de Waal RM: Vascular endothelial growth factor-A(165) induces progression of melanoma brain metastases without induction of sprouting angiogenesis. Cancer Res 2002, 62:34I-345.

15. Leenders WP, Kusters B, de Waal RM: Vessel co-option: how tumors obtain blood supply in the absence of sprouting angiogenesis. Endothelium 2002, 9:83-87.

16. Leenders W, Kusters B, Pikkemaat J, Wesseling P, Ruiter D, Heerschap A, Barentsz J, de Waal RM: Vascular endothelial growth factor-A determines detectability of experimental melanoma brain metastasis in GD-DTPA-enhanced MRI. Int J Cancer 2003, 105:437-443.

17. Dome B, Paku S, Somlai B, Timar J: Vascularization of cutaneous melanoma involves vessel co-option and has clinical significance. J Pathol 2002, 197:355-362.

18. Vermeulen PB, Colpaert C, Salgado R, Royers R, Hellemans H, Van Den HE, Goovaerts G, Dirix LY, Van Marck E: Liver metastases from colorectal adenocarcinomas grow in three patterns with different angiogenesis and desmoplasia. J Pathol 200I, 195:336-342

19. Leenders WP, Kusters B, Verrijp K, Maass C, Wesseling P, Heerschap $A$, Ruiter D, Ryan A, De Waal R: Antiangiogenic therapy of cerebral melanoma metastases results in sustained tumor progression via vessel co-option. Clin Cancer Res 2004, i 0:6222-6230.

20. van Kempen LC, Leenders WP: Tumours can adapt to anti-angiogenic therapy depending on the stromal context: lessons from endothelial cell biology. Eur J Cell Biol 2006, 85:6I-68.

21. Claes A, Wesseling P, Jeuken J, Maass C, Heerschap A, Leenders WP: Antiangiogenic compounds interfere with chemotherapy of brain tumors due to vessel normalization. Mol Cancer Ther 2008, 7:71-78.

22. Roodink I, Raats J, Zwaag B van der, Verrijp K, Kusters B, Van Bokhoven H, Linkels M, de Waal RM, Leenders WP: Plexin DI expression is induced on tumor vasculature and tumor cells: a novel target for diagnosis and therapy? Cancer Res 2005, 65:8317-8323.

23. Tamagnone L, Artigiani S, Chen H, He Z, Ming GI, Song H, Chedotal A, Winberg ML, Goodman CS, Poo M: Plexins are a large family of receptors for transmembrane, secreted, and GPIanchored semaphorins in vertebrates. Cell 1999, 99:7I-80.

24. Gherardi E, Love CA, Esnouf RM, Jones EY: The sema domain. Curr Opin Struct Biol 2004, 14:669-678. 
25. Rohm B, Ottemeyer A, Lohrum M, Puschel AW: Plexin/neuropilin complexes mediate repulsion by the axonal guidance signal semaphorin 3A. Mech Dev 2000, 93:95-104.

26. Nakamura F, Kalb RG, Strittmatter SM: Molecular basis of semaphorin-mediated axon guidance. J Neurobiol 2000, 44:2 19-229.

27. Fujisawa H: Discovery of semaphorin receptors, neuropilin and plexin, and their functions in neural development. J Neurobiol 2004, 59:24-33.

28. Takahashi T, Fournier A, Nakamura F, Wang LH, Murakami Y, Kalb RG, Fujisawa H, Strittmatter SM: Plexin-neuropilin- I complexes form functional semaphorin-3A receptors. Cell I999, 99:59-69.

29. Zwaag B van der, Hellemons AJ, Leenders WP, Burbach JP, Brunner HG, Padberg GW, Van Bokhoven H: PLEXIN-DI, a novel plexin family member, is expressed in vascular endothelium and the central nervous system during mouse embryogenesis. Dev Dyn 2002, 225:336-343

30. Gitler AD, Lu MM, Epstein JA: PlexinD I and semaphorin signaling are required in endothelial cells for cardiovascular development. Dev Cell 2004, 7:107-II6.

31. Torres-Vazquez J, Gitler AD, Fraser SD, Berk JD, Van NP, Fishman MC, Childs S, Epstein JA, Weinstein BM: Semaphorin-plexin signaling guides patterning of the developing vasculature. Dev Cell 2004, 7:117-123.

32. Zhang $Y$, Singh MK, Degenhardt KR, Lu MM, Bennett J, Yoshida $Y$, Epstein JA: Tie2Cre-mediated inactivation of plexinD I results in congenital heart, vascular and skeletal defects. Dev Biol 2009, 325:82-93.

33. Roodink I, Kats G, van Kempen L, Grunberg M, Maass C, Verrijp K, Raats J, Leenders W: Semaphorin 3E Expression Correlates Inversely with Plexin DI During Tumor Progression. Am J Pathol 2008, I73:1873-188I.

34. Toyofuku T, Yabuki M, Kamei J, Kamei M, Makino N, Kumanogoh A Hori M: Semaphorin-4A, an activator for T-cell-mediated immunity, suppresses angiogenesis via Plexin-DI. EMBO J 2007, 26: 1373-1384

35. Kigel B, Varshavsky A, Kessler O, Neufeld G: Successful inhibition of tumor development by specific class-3 semaphorins is associated with expression of appropriate semaphorin receptors by tumor cells. PLoS ONE 2008, 3:e3287.

36. Santimaria M, Moscatelli G, Viale GL, Giovannoni L, Neri G, Viti F, Leprini A, Borsi L, Castellani P, Zardi L: Immunoscintigraphic detection of the ED-B domain of fibronectin, a marker of angiogenesis, in patients with cancer. Clin Cancer Res 2003, 9:571-579.

37. Castellani P, Borsi L, Carnemolla B, Biro A, Dorcaratto A, Viale GL, Neri D, Zardi L: Differentiation between high- and low-grade astrocytoma using a human recombinant antibody to the extra domain-B of fibronectin. Am J Pathol 2002, I 6 I: | 695- I700.

38. Schraa AJ, Kok RJ, Moorlag HE, Bos EJ, Proost JH, Meijer DK, de Leij LF, Molema G: Targeting of RGD-modified proteins to tumor vasculature: a pharmacokinetic and cellular distribution study. Int J Cancer 2002, I 02:469-475.

39. Janssen ML, Oyen WJ, Dijkgraaf I, Massuger LF, Frielink C, Edwards DS, Rajopadhye M, Boonstra H, Corstens FH, Boerman OC: Tumor targeting with radiolabeled alpha(v)beta(3) integrin binding peptides in a nude mouse model. Cancer Res 2002 62:6|46-6|5|

40. Dijkgraaf I, Kruijtzer JA, Frielink C, Corstens FH, Oyen WJ, Liskamp RM, Boerman OC: Alpha $\mathbf{v}$ beta 3 integrin-targeting of intraperitoneally growing tumors with a radiolabeled RGD peptide. Int J Cancer 2007, I 20:605-6I0.

41. Dienst A, Grunow A, Unruh M, Rabausch B, Nor JE, Fries JW Gottstein C: Specific occlusion of murine and human tumor vasculature by VCAM-I-targeted recombinant fusion proteins. J Natl Cancer Inst 2005, 97:733-747.

42. Rafii S, Avecilla ST, Jin DK: Tumor vasculature address book: identification of stage-specific tumor vessel zip codes by phage display. Cancer Cell 2003, 4:33I-333.

43. Kuroda H, Tamaru J, Sakamoto G, Ohnisi K, Itoyama S: Immunophenotype of lymphocytic infiltration in medullary carcinoma of the breast. Virchows Arch 2005, 446:10-14.

44. Saravanamuthu J, Reid WM, George DS, Crow JC, Rolfe KJ, MacLean $A B$, Perrett $C W$ : The role of angiogenesis in vulvar cancer, vulvar intraepithelial neoplasia, and vulvar lichen sclerosus as determined by microvessel density analysis. Gynecol Oncol 2003, 89:25I-258.
45. Gambino LS, Wreford NG, Bertram JF, Dockery P, Lederman F, Rogers PA: Angiogenesis occurs by vessel elongation in proliferative phase human endometrium. Hum Reprod 2002, I7:|199-1206.

\section{Pre-publication history}

The pre-publication history for this paper can be accessed here:

http://www.biomedcentral.com/1471-2407/9/297/pre pub
Publish with Biomed Central and every scientist can read your work free of charge

"BioMed Central will be the most significant development for disseminating the results of biomedical research in our lifetime. "

Sir Paul Nurse, Cancer Research UK

Your research papers will be:

- available free of charge to the entire biomedical community

- peer reviewed and published immediately upon acceptance

- cited in PubMed and archived on PubMed Central

- yours - you keep the copyright 